\title{
EVIDENCE OF SOMATIC EMBRYOGENESIS FROM ROOT TIP EXPLANTS OF THE RATTAN CALAMUS MANAN
}

\author{
D. K. S. GOH, N. MICHAUX-FERRIERE, ${ }^{1}$ O. MONTEUUIS, AND M.-C. BON \\ CIRAD-Forêt and ICSB Joint Project, P.O. Box 60793, 91017 Tawau, Sabah, Malaysia (D. K. S. G., M.-C. B.), CIRAD-Biotrop, BP \\ 5035, 34032 Montpellier Cedex 1, France (N. M.-F.), and Cirad-Forêt, Campus de Baillarguet, RP 5035, 34032 Montpellier \\ Cedex 1, France (O.M.)
}

(Received 10 February 1999; accepted 2 June 1999; editor T. A. Thorpe)

\begin{abstract}
SUMMARY
Somatic embryogenesis of Calamus manan, a single-stemmed rattan species, in tissue culture was scientifically demonstrated for the first time. Root tips of in vitro plantlets produced friable callus when the explants were cultivated for several mo. on a Murashige and Skoog induction medium containing $7.5 \mathrm{mg}$ Picloram per 1 (31.1 $\mu M)$. Histological analyses established the presence of proembryos within the callus which differentiated subsequently into somatic embryos using the same culture medium. Histological examination revealed that these somatic embryos completely lacked starch and protein reserves, which did not prevent them, however, from germinating, and showing bipolar development. These somatic embryos further developed into young plants, similarly to zygotic embryos.
\end{abstract}

Key words: Calamus manan; histology; in vitro culture; somatic embryogenesis; rattan.

\section{INTRODUCTION}

Rattans are spiny climbing palms that grow in tropical rainforests and are very much prized for furniture making. Among the largecaned Calamus spp., the single-stemmed Calamus manan is one of the most valuable in terms of market demand. Its overexploitation, especially during the last decade, has accounted for a dramatic depletion of natural resources from Peninsular Malaysia and Sumatra from where the species originates. To remedy this critical situation, the species has been intensively planted within industrial forestry projects over the past $10 \mathrm{yr}$, particularly in Sabah, East Malaysia (Nasi and Monteuuis, 1992; Goh et al., 1997).

Seeds have been the most widely used means for propagating the prolific $C$. manan, although vegetative propagation can be useful for improving the genetic quality of the planting stock (Goh et al., 1997). Owing to the limitations of horticultural techniques for vegetatively propagating this single-stemmed species (Aziah and Manokaran, 1985), tissue culture methods have been emphasized (Alloysius and Bon, 1996). In vitro shoot proliferation from juvenile plants has been proven to be feasible when one uses shoot tips from in vitro-germinated or nursery seedlings (Aziah and Manokaran, 1985; Umali-Garcia, 1985). Nevertheless, Goh et al. (1997) observed an overall limited multiplication rate and high variability of responses among explants. The possibility of applying this technology for cloning mature selected individuals appeared particularly attractive (Goh et al., 1997). However, the risks of losing the superior genotypes associated with use of the sole shoot apex as primary explant led us to investigate the applicability of other techniques. Among the different regeneration methods developed on the nonsexual tissues of palms, regardless of the type and the age of the initial explant, somatic

${ }^{1}$ To whom correspondence should be addressed at e-mail ferriere@cirad.fr. embryogenesis has been the most remarkable (Hanower and Pannetier, 1982; Dublin et al., 1991) and was hence attempted on Calamus manan as reported for the first time in this paper. Various kinds of primary explants such as root tips, leaf portions, and maternal tissues of the flowers were tested with respect to their potential for somatic embryogenesis. Emphasis was placed on roots, which are abundant and easy to obtain in rattans. Ex vitro materials had failed so far to produce responsive callus mainly due to inappropriate disinfection protocols. In contrast, roots obtained in vitro could be induced to form somatic embryos. The conversion of these embryos into plantlets were successful. These were compared to in vitro seedlings as a reference. Histological analysis was undertaken to ascertain the somatic origin of the embryos obtained and to better understand the whole process with a view to improving its efficiency.

\section{Materials and Methods}

Somatic embryogenesis. Microshoots were obtained by axillary budding from young C. manan seedlings germinated in vitro (Goh et al., 1997). Root tip fragments (1-2 cm long) were excised from the most terminal part of the primary roots of these microshoots to be inoculated for callus formation without any further disinfection treatments. Root explants were cut once longitudinally before being placed on Murashige and Skoog (1962) macro- and micronutrients supplemented with (per l) $100 \mathrm{mg}$ myo-inositol, $500 \mathrm{mg}$ casein hydrolysate, $2 \mathrm{mg}$ glycine, $1 \mathrm{mg}$ thiamine, $1 \mathrm{mg}$ pyridoxine-HCL, $1 \mathrm{mg}$ nicotinic acid, $30 \mathrm{~g}$ sucrose, and $7.5 \mathrm{mg}$ picloram (4-amino-3,5,6-trichloropicolinic acid). After $\mathrm{pH}$ adjustment to $5.6-5.8$ with $1 N \mathrm{KOH}$ and the addition of $7 \mathrm{~g}$ "high gel strength" Sigma agar (cat. n A-9799 Sigma Chemical Co., St. Louis, MO, USA) per $1,12.5 \mathrm{ml}$ of the medium was dispensed into $21 \times$ $150-\mathrm{mm}$ glass test tubes prior to sterilization by autoclaving at $120^{\circ} \mathrm{C}$ and $95 \mathrm{kPa}$ for $20 \mathrm{~min}$. After inoculation, the cultures were maintained in these glass tubes covered with polypropylene caps in total darkness at $27 \pm 2^{\circ} \mathrm{C}$ and relative humidity $(\mathrm{RH})$ about $90 \%$.

The callus obtained was subcultured once onto the same culture medium as described above. Thereafter, they were divided and transferred several 


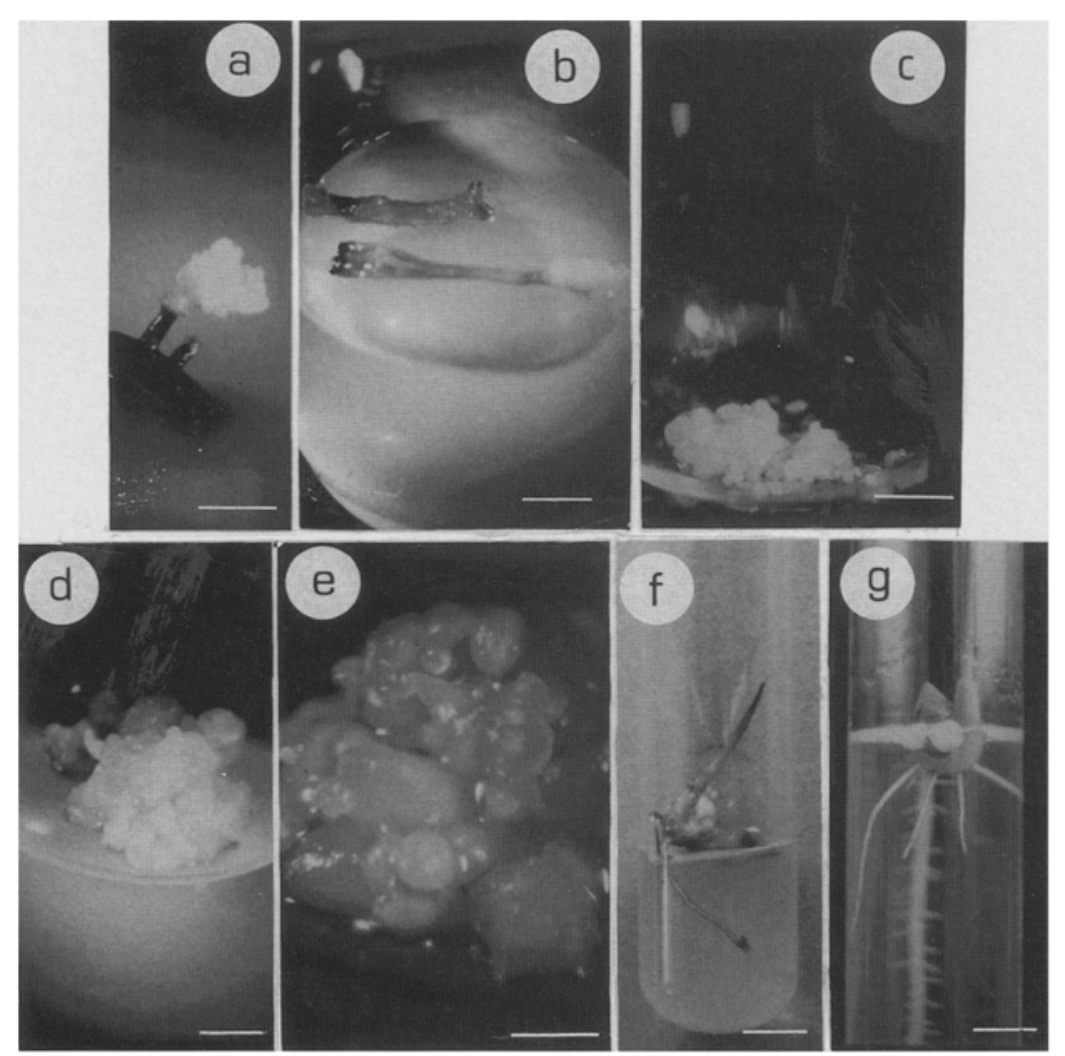

Fic. 1. Morphological aspects of somatic embryogenesis in rattan. $a$, Primary and creamy callus proliferating on an apex of a secondary root explant; bar, $0.5 \mathrm{~cm}$. b. Primary callus proliferating at the cut parts and the apex of a primary root explant; $b a r, 0.5 \mathrm{~cm} . c$, Nodular callus after several mo. of culture; bar, $1 \mathrm{~cm} . d$, Translucent and milky white globules on callus; bar, $1 \mathrm{~cm}$. e, Embryo-like structures at different stages of development; $b a r, 0.3 \mathrm{~cm}, f$, Somatic embryo-derived plantlet or embling; $b a r, 1 \mathrm{~cm} . g$, Seedling; bar, 0.5 $\mathrm{cm}$.

times at 4- to 8-wk intervals onto a maturation medium with picloram ranging from 1 to $5 \mathrm{mg} \mathrm{l}^{-1}$ (4.I to $20.7 \mu M$ ).

Somatic embryo maturation, germination and conversion. The embryos developed were subcultured again at 4- to 8 -wk intervals onto the same basal culture medium but without growth regulators. The embryos were considered as germinated once there was plumule onset. They were then transferred to light conditions at $26 \pm 2^{\circ} \mathrm{C}$, and $\mathrm{RH}$ about $70 \%$. The development of the first leaf from the shoot apex together with the elongation of the radicle occurred soon after. This marked the completion of the conversion process.

Histology. The specimens selected for histological analysis were fixed for $24 \mathrm{~h}$ in a phosphate buffer $(0.2 \mathrm{M}, \mathrm{pH} 7.2)$ containing $2 \%$ paraformaldehyde, $1 \%$ glutaraldehyde, and $1 \%$ caffeine to precipitate oxidized phenol compounds in situ. After dehydration through a graded alcohol series, samples were then embedded in LKB resin (Leica Rueil-Malmaison, France) and cut in $3-\mu \mathrm{m}$-thick sections. For each specimen studied, sections were doublestained with periodic acid Schiff (PAS) and Naphthol blue black (NBB). PAS stained starch reserves and cell walls red (Martoja and Martoja, 1967) and NBB specifically stained soluble or reserve proteins blue-black (Fisher, 1968).

\section{Results}

Different explants such as young leaves and roots from in vitrogerminated seedlings were used for the induction of callogenesis. However, only root explants were observed to progress beyond the initial callogenesis stage. Our effort in this study was therefore concentrated primarily on this type of explant.

Morphological observations of somatic embryogenesis. Callogenesis was first observed on several explants 3 to $6 \mathrm{mo}$. after the date of inoculation. Primary callus occurred on apices of primary or secondary roots (Fig. $1 \mathrm{a}$ ). It also proliferated along the cut surface of the root as protuberances of the central cylindrical zone (Fig. $1 \mathrm{~b}$ ). In the early phase of the process, a mixture of white and friable primary callus was formed. This type of callus was usually creamy to yellowish in its later stages.

Eleven mo. after initiation, the calluses were divided. Callus that was subcultured several times onto the basal medium with $7.5 \mathrm{mg}$ picloram per 1 to allow for proliferation became compact and brown, while that transferred to media with lower auxin levels (1 to $5 \mathrm{mg}$ $1^{-1}$ ) took on a nodular appearance (Fig. $1 c$ ). These nodules displayed either a smooth or rough surface. At this stage, we frequently observed within the same callus a mixture of nonfriable callus with a nodular and irregularly-shaped appearance.

In the subsequent stage, these nodules gave rise to more glossy, translucent, and globular protuberances (Fig. $1 d, e$ ). On the basis of these morphological aspects, they could be considered as promising somatic embryos and preferably selected. These embryos eventually showed bipolar development.

Somatic embryo germination and conversion. A mixture of embryos at different stages was obtained after they were transferred onto medium with lower concentrations of the growth regulator. The apex of the embryos became elongated and greenish. When subcultured onto a hormone-free medium, the embryos germinated. At almost the same time, a structure which looked like the haustorium developed by the embryos of rattans could be observed adjacent to the basal portion of the embryo and conjointly, a plumule emerged (Fig. $1 \mathrm{f}$ ). Development was quite slow and occurred over a period of 2 to 4 mo. following the transfer onto medium without picloram. The transfer to lighted conditions at the beginning of the germination phase led soon after to the development of the first leaf. A visual comparison of these plantlets and the seedling (Fig. $1 \mathrm{~g}$ ) showed similar morphological features.

Histological data. The callus was formed from the explant by the 


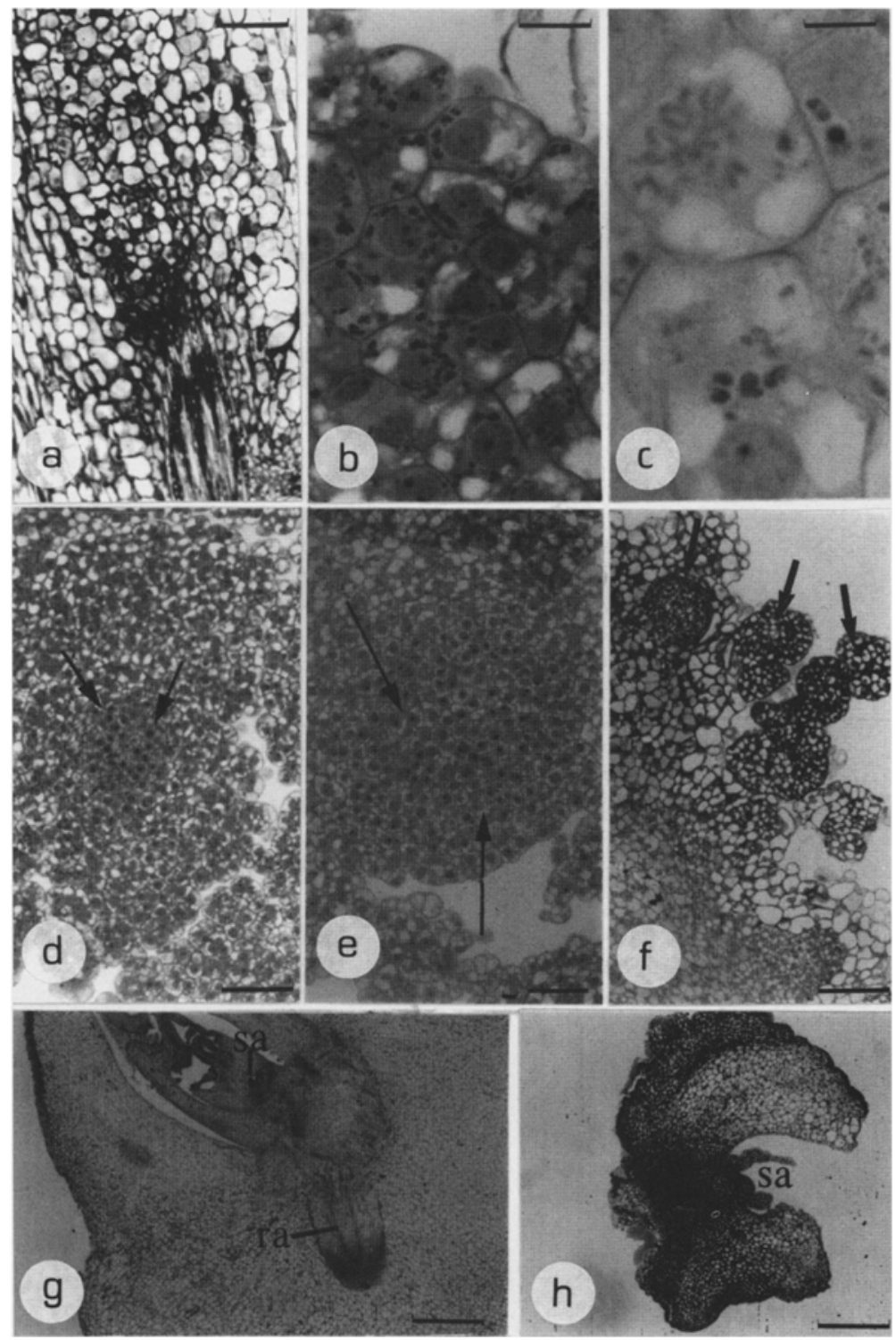

FIG. 2. Histological aspects of the formation of somatic embryogenesis in rattan. $a$, Callus originating from perivascular cells of the root explant; bar, $160 \mu \mathrm{m}$. $b$, Dedifferentiating cells within a callus; bar, $20 \mu \mathrm{m} . c-e$, First mitosis $(c$, bar, $8 \mu \mathrm{m})$ giving rise to a zone of embryonic cells (arrows: $d$, bar, $80 \mu \mathrm{m} ; e$, bar, $40 \mu \mathrm{m}) . f$, Proembryos arising (arrows) from degenerating callus. Bar, $80 \mu \mathrm{m}$. $g$, Shoot (sa) and root apices ( $\mathrm{ra}$ ) of a zygotic embryo. $B a r, 300 \mu \mathrm{m}$. $h$, Histological aspect of a somatic embryo; sa, shoot apex. Bar, $600 \mu \mathrm{m}$.

multiplication of cortical (Fig. $2 a$ ) and meristematic cells. Two types of primary callus were observed: a friable callus consisting of highly differentiated cells which were separated from each other (data not shown), and a white callus of nondifferentiated cells which appeared highly clustered (Fig. 2 b). More or less vacuolized, these latter cells exhibited a large nucleus with an obvious nucleolus and few starch reserves. Some cells among this uniformly structured callus divided (Fig. 2 c). This new generation of cells, while losing their starch reserves, was becoming "embryonic" cells, actively dividing with a higher nucleoplasmic ratio and an enlarged nucleolus (Fig. $2 d, e$ ). These cells gave rise to delimited and embryonic zones (Fig. $2 d, e$ ) which developed independently from the rest of the callus. These zones which proved from their later development to be proembryos were still very closely embedded in the callus. The proembryos corresponding to the nodules morphologically observed emerged rapidly from the degeneration of the surrounding cells (Fig. $2 f$ ).

It became clear that although the initiation of the proembryo units was usually synchronous, their development was erratic in the later stage of culture. It was common to observe within the same callus some proembryos with newly formed epidermis, as well as embryos exhibiting their apical meristem with leaf primordia and even embryos with axillary buds. In addition, a few proembryos were in the process of degenerating. Unlike in zygotic embryos (Fig. $2 \mathrm{~g}$ ) which exhibited limited starch and protein reserves, no reserves at all were detected in the embryonic body (Fig. $2 h$ ). Several embryos also showed abnormalities such as the presence of several apical meristems or multiple foliar primordia. Since ontogenesis appeared to be abnormal, this could explain the weak germinating capacity of the embryos.

\section{DISCUSSION}

Somatic embryogenesis of tropical plants such as oil palm and coffee have been successfully developed with some procedures transferred from the laboratory to the industrial production units (Hanower and Pannetier, 1982; Schwendiman et al., 1988; Zammarippa et al., 1991). However, none of these concerned rattans. On the basis of protocols from researchers on other species, with special reference to oil palm (Brackpool et al., 1986) and date palm (Zaid, 1989; Ben- 
badis, personal communication), attempts at inducing somatic embryogenesis from Calamus manan root tips with picloram as the auxin was successful. Moreover, histological analyses, which have been essential for the understanding of somatic embryogenesis of other palm species (Schwendiman et al., 1988, 1990) confirmed the evidence of somatic embryogenesis reported in this study for Calamus manan.

In rattans, the primary callus proliferated from the root apex or the central cylindrical zone. It seemed to be organized from both perivascular and meristematic cells. However, in palms, the onset of embryogenesis is recognized to be of multicellular origin (Schwendiman et al., 1988). The rattans deviate from this model, as embryogenesis appeared to be of unicellular origin under the current culture conditions used. The same pattern was observed for the induction of somatic embryogenesis in coffee in liquid medium by Zammarippa (1993). According to Schwendiman et al. (1988) and Michaux-Ferrière et al. (1992), the culture conditions may have a determining influence on the uni- or multicellular origin of the somatic embryogenesis process. Subsequently, if the origin were indeed unicellular, rattan somatic embryogenesis might be considered as a preferential method of regeneration following future genetic transformation. since the origin of the embryos developed could be determined.

Besides the proembryos, visual observation of the callus revealed numerous irregularly-shaped structures and big globular masses with a light brown coating. On the basis of histological examination, these irregularly-shaped structures could be identified as degenerating cell masses which were oxidized by phenolic compounds, as observed in these globular masses. As emphasized by many authors, the callus quality was of prime importance in the somatic embryogenesis process. This condition influenced the establishment of the most appropriate subsequent sequences. Moreover, under the culture conditions defined above, somatic embryos were developed in a completely random manner, thereby leading to inefficient production of somatic embryos.

It was interesting to note the presence of secondary somatic embryos developing on primary somatic embryos in some cases. It is still unknown what determined the formation of these secondary embryos and their histological origin.

Since there was no information at the organogenesis level of rattan zygotic embryos in the literature, somatic embryos were compared at the morphological and developmental levels only and appeared to be quite similar. Rattan somatic embryos are able to germinate and to be converted into emblings, if suitably formed. A cotyledonary notch formed at the base of the somatic embryo, and both apical and root apices were present. As described for oil palm (Schwendiman et al., 1988), during germination of zygotic embryos, the cotyledonary structure is transformed into a highly vascularized green haustorium, which ensures the growth of the seedlings by digestion of the endosperm. In rattan, normal somatic embryos also exhibited a so-called "cotyledonary lamina," which was dome-shaped and yellowish, but could not be called a haustorium according to Tomlinson (1990) since there were no reserves. According to Schwendiman et al. (1988), this structure would have enabled the growth of the embryos by taking up nutrients from the culture medium.

The formation of abnormal embryos, particularly with multiple foliar primordia as observed in Calamus manan which is considered a single-stemmed species, could have resulted from a defect in ontogenesis. The presence of a high concentration of growth regulators before and during the maturation of the proembryos might be a cause of such abnormalities. Apart from an ontogenetic defect, polarity deficiency could also lead to morphogenetic abnormalities. As stressed by Michaux-Ferrière et al. (1992) in Hevea brasiliensis, poor regulation of the sequences whereby a group of cells "cooperate" to form a somatic embryo may lead to polarity defects and thus, to abnormalities. In general, data are still unavailable to establish the reasons for such a phenomenon.

Evidence of somatic embryogenesis of Calamus manan has been demonstrated here for the first time. Nonetheless, the procedure developed in this paper would need considerable improvement before it could be realistically adopted for large-scale applications. By adopting a histological approach, it is hoped that further progress in modulating the whole process of the formation of the somatic embryos, particularly those with potential for plant regeneration, can be achieved. Emphasis would be placed particularly on shortening the process and defining proper media for better synchronous development of the proembryos.

\section{REFERENCES}

Alloysius, D.; Bon, M. C. Joint rattan research between Innoprise Corporation Sdn Bhd and CIRAD-Forêts in Sabah, Malaysia. In: Genetic enhancement of bamboo and rattan. INBAR Technical Report 7, INBAR New Dehli; 1996:111-125.

Aziah, M. Y.; Manokaran, N. Seed and vegetative propagation of rattans. In: Proceedings of the Rattan Seminar, Kuala Lumpur, 2-4 October 1984; 1985:13-21.

Brackpool, A. L.; Branton, R. L.; Blake, J. Regeneration in palms. In: Vasil, I. K., ed. Cell culture and somatic cell genetics of plants. Vol. 3. Plant regeneration and genetic variability. London: Academic Press; 1986:207-222.

Dublin, P.; Enjalric, F.; Lardet, L.; Carron, M.-P.; Trolinder, N.; Pannetier, C. Estate crops. In: Debergh, P. C.; Zimmerman, R. H., ed. Micropropagation: technology and application. Dordrecht, The Netherlands: Kluwer Academic Publishers; 1991:337-361.

Fisher, D. B. Protein staining of ribboned epon sections for light microscopy. Histochemie 16:92-96; 1968.

Goh, D. K. S.; Bon, M. C.; Monteuuis, O. Prospects of biotechnology for a rattan improvement programme. Bois For. Trop. 254:51-67; 1997.

Hanower, J.; Pannetier, C. In vitro vegetative propagation of the oil palm, Elaeis guineensis Jacq. In: Fujiwara, A., ed. Plant tissue culture. Tokyo: Maruzen: 1982:745-746.

Martoja, R.; Martoja, M. Initiation aux techniques de l'histologie animale. Paris: Masson et Cie; 1967; 345 p.

Michaux-Ferrière, N.; Grout, H.; Carron, M. P. Origin and ontogenesis of somatic embryos in Hevea Brasiliensis (Euphorbiaceae). Am. J. Bot. 79:174-180; 1992.

Murashige, T.; Skoog, F. A revised medium for rapid growth and bioassays with tobacco tissue cultures. Physiol. Plant. 15:473-497; 1962.

Nasi, R.; Monteuuis, O. Un nouveau programme de recherches au Sabah: le rotin. Bois For. Trop. 232:15-25; 1992.

Schwendiman, J.; Pannetier, C.; Michaux-Ferrière, N. Histology of somatic embryogenesis from leaf explants of the oil palm Elaeis guineensis Ann. Bot. 62:43-52: 1988.

Schwendiman, J.; Pannetier, C.; Michaux-Ferrière, N. Histologie des formations embryogènes obtenues au cours de la culture in vitro du palmier à huile Elaeis guineensis Jacq. Oléagineux 45:416-418; 1990.

Tomlinson, P. B. The structural biology of palms. New York: Oxford University Press; 1990: 477 p.

Umali-Garcia, M. Tissue culture of some rattan species. In: Proceedings of the Rattan Seminar, Kuala Lumpur, 2-10 October 1984; 1985:2331 .

Zaïd, M. Embryogenèse somatique chez le palmier dattier Phoenix dactylifera. Ph.D. Thesis, University Orsay-Paris Sud; 1989.

Zamarripa, A. Etude et développement de l'embryogenèse somatique en milieu liquide du caféier (Coffea canephota, Coffea arabica et l'hybride Arabusta). Ph.D. Thesis, Ecole Nationale Supérieure Agronomique de Rennes; 1993.

Zamarripa, A.; Ducos, J. P.; Bollon, H.; Dufour, M.; Petiard. V. Production d'embryons somatiques de cafeier en milieu liquide: effets densité d'inoculation et renouvellement du milieu. Café Cacao Thé 35:233244; 1991 